\title{
Game Edukasi Tugu Pahlawan Surabaya Dengan Augmented Reality Berbasis Android
}

\author{
Radifan Aufar Pratama, Maulana Rizqi \\ Program Studi Sistem Komputer, Universitas Narotama Surabaya \\ J1. Arief Rahman Hakim No. 51 Surabaya. \\ radifanap@gmail.com,maulana.rizqi@narotama.ac.id \\ Diterima : 23 Februari 2021 \\ Disetujui : 28 Maret 2021
}

\begin{abstract}
Abstrak-Tugu Pahlawan Surabaya merupakan sebuah monumen yang menjadi markah bagi Kota Surabaya. Tugu Pahlawan dibangun untuk memperingati peristiwa Pertempuran 10 November 1945 di Surabaya, di mana para warga Surabaya berjuang melawan pasukan Sekutu bersama Belanda yang hendak menjajah kembali Indonesia. Game Edukasi Tugu Pahlawan Surabaya Dengan Augmented Reality Berbasis Android ini dibuat untuk meningkatkan kesadaran masyarakat tentang pentingnya menghargai para pahlawan yang sudah memperjuangkan kemerdekaan Indonesia, terlebih lagi di era globalisasi saat ini, informasi dan game mudah diakses oleh siapa saja. Augmented Reality adalah teknologi yang memperoleh penggabungan waktu nyata terhadap digital konten yang dibuat oleh komputer dengan dunia nyata. Augmented Reality memperbolehkan pengguna melihat objek maya 2D atau 3D yang diproyeksikan terhadap dunia nyata. Aplikasi dibuat menggunakan Game Engine Unity 3D, dan dengan menggunakan Android sebagai sistem operasi. Kuisioner digunakan sebagai tolak ukur penilaian pendapat terhadap aplikasi. Berdasarkan kuisioner pengujian aplikasi terhadap pengguna didapatkan hasil $83.13 \%$ yaitu kategori sangat baik.
\end{abstract}

Kata Kunci : Tugu Pahlawan Surabaya, Augmented Reality, Unity3D, Android.

\section{PENDAHULUAN}

Perkembangan teknologi zaman sekarang terjadi dengan sangat cepat salah satunya teknologi informasi, terutama smartphone. Di Indonesia sendiri banyak jenis smartphone yang sudah tersebar luas dengan harga yang bermacam-macam, terlebih lagi sekarang harga smartphone makin mudah dijangkau oleh masyarakat, dan hal tersebut membuat smartphone menjadi pilihan hampir sebagaian besar masyarakat Indonesia. Menurut data, pengguna smartphone di Indonesia sendiri sudah mencapai 92 Juta orang (eMarketer, 2019). Sistem Operasi atau yang biasa dikenal dengan OS yang paling banyak digunakan adalah sistem operasi berbasis Android. Data yang diambil dari laman StatCounter (2019) menyebutkan pengguna smartphone berbasis OS Android di seluruh dunia sebanyak $76.23 \%$, dan iOS hanya $22.17 \%$, sedangkan di Indonesia pengguna smartphoneberbasis OS Android sebanyak $93.85 \%$, dan iOS hanya $5.24 \%$ per Agustus
2019. Dengan berkembangnya smartphone, banyak pula fitur yang berkembang yang dapat digunakan di smartphone, salah satunya adalah Augmented Reality. Menurut Wikipedia, Augmented Reality adalah adalah teknologi yang menggabungkan benda maya dua dimensi dan ataupun tiga dimensi ke dalam sebuah lingkungan nyata tiga dimensilalu memproyeksikan benda-benda maya tersebut dalam waktu nyata.

Banyak orang yang melupakan sejarah karena mempelajari sejarah adalah hal yang membosankan, dan orang tidak akan merasa tertarik. Walaupun sudah banyak media yang mempermudah orang untuk belajar tentang sejarah, masih banyak orang yang tetap tidak menghiraukan tentang sejarah. Augmented Reality dapat dijadikan sarana belajar yang menarik, dapat meningkatkan minat belajar masyarakat dan tidak membosankan. Pada penelitian yang berjudul "Aplikasi Augmented Reality Game Edukasi Untuk Pengenalan Organ 
Tubuh Manusia", penelitian ini merancang dan membangun aplikasi augmented reality game edukasi dengan metode SDLC (System Development Life Cycle). Aplikasi dibangun dengan menggunakan Unity 3D, Blender sebagai modelling, vuforia SDK untuk membentuk Augmented Reality, dan Playmaker sebagai pemrograman. Aplikasi tersebut memiliki permainan tentang soal yang diambil dari materi pengenalan organ tubuh manusia.[1]

Berdasarkan dari pemaparan yang sudah di uraikan diatas, peneliti mengambil judul proyek akhir yaitu "Game Edukasi Tugu Pahlawan Surabaya Dengan Augmented Reality Berbasis Android". Dengan adanya aplikasi ini diharapkan dapat menambah minat belajar masyarakat untuk belajar sejarah, sebagai contoh adalah sejarah Tugu Pahlawan Surabaya.

\section{LANDASAN TEORI}

\section{A. Augmented Reality}

Ronald Azuma pada tahun 1997 mendefinisikan Augmented Reality sebagai berikut: Menggabungkan lingkungan nyata dan virtual, berjalan secara interaktif dalam waktu nyata, dan integrasi dalam tiga dimensi (3D). [2]

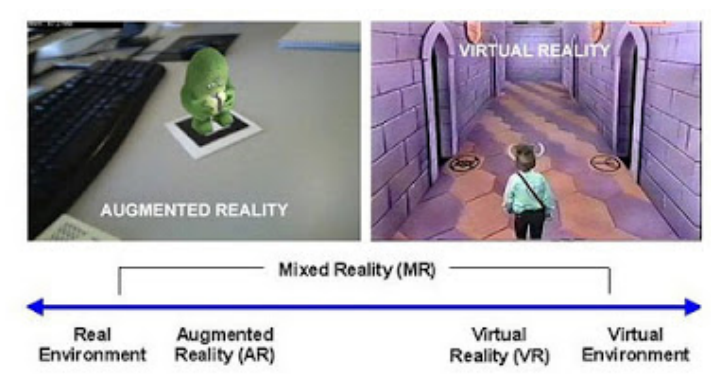

Gambar 1. Perbedaan dari Augmented Reality dan Virtual Reality

\section{B. Markerless Augmented Reality}

Markerless merupakan metode dalam pengembangan AR tanpa harus menggunakan marker. Markerless digunakan dalam pelacakan objek yang ada pada dunia nyata untuk diproyeksikan ke dalam dunia maya tanpa memiliki marker yang spesial. [3] Pada proses markerless, penggunaan marker atau penanda digantikan dengan pengenalan pola atau pattern recognition, dimana setiap objek memiliki pola yang unik yang membuat pengenalan setiap objek bisa menjadi berbeda. Fitur alami yang dimiliki setiap objek yang dapat diambil untuk pengenalan pola atau pattern recognition adalah tepi, sudut, garis, maupun objek 3D.

\section{Unity 3D}

Unity 3D adalah sebuah aplikasi yang digunakan untuk membuat game atau sering juga disebut dengan game engine. Pada dasarnya unity merupakan game engine yang berbasis $3 \mathrm{D}$ namun unity juga bisa digunakan untuk membuat game 2D. [4]

Unity 3D digunakan sebagai penggabung filefile yang sudah disediakan atau yang akan dibuat, beberapa file yang bisa digabungkan untuk membuat game antara lain objek 3D atau 2D yang sudah dibuat, program yang sudah dibuat, animasi dan sebagainya.

\section{Blender}

Blender adalah rangkaian kreasi 3D yang gratis dan open source. Blender mendukung konsep 3D secara keseluruhan-modeling, rigging, animasi, simulasi, rendering, compositing, dan motion tracking, bahkan video editing dan pembuatan game.[5]

\section{METODE PENELITIAN}

Prosedur penelitian yang terstruktur dapat membantu penyelesaian masalah yang dibahas dalam penelitian ini. Metode yang ditulis dalam penelitian ini mencangkup, analisa permasalahan, dan perancangan.

\section{A. Analisa Permasalahan}

Dalam perancangan aplikasi ini, pada saat kamera handphone diarahkan ke ground plane atau bangun datar, akan ada perintah untuk menggerakkan kamera perlahan, jika sudah selesai proses scan tersebut, aplikasi akan memberi perintah untuk meletakkan objek AR 3 dimensi tersebut, kemudian aset 3 dimensi yang sudah di buat dari aplikasi Blender akan muncul. 


\section{B. Perancangan Aplikasi}

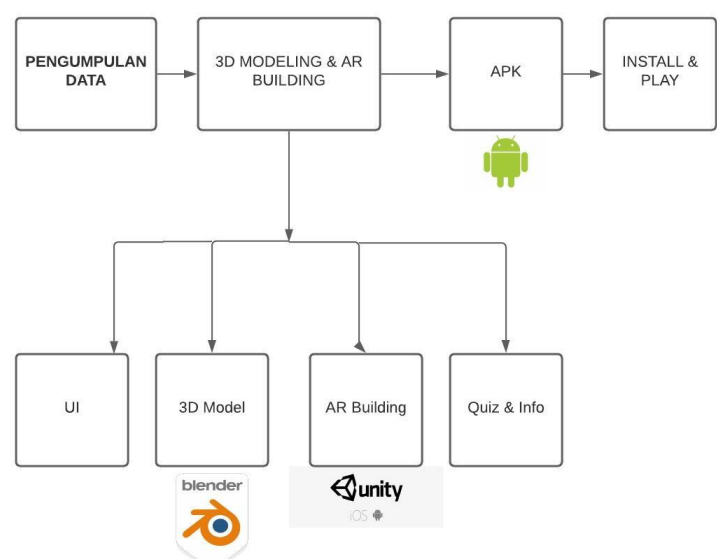

Gambar 2. Rancangan Aplikasi

Rancangan gambar diatas merupakan urutan langkah pembuatan aplikasi. Dimulai dari pengambilan data, pembuatan objek 3D menggunakan Blender dan di export ke dalam format .fbx, pembuatan desain UI menggunakan Photoshop, pembuatan data kuis dan informasi menggunakan Microsoft Excel dan Microsoft Word, kemudian pembuatan aplikasi menggunakan Unity 3D, setelah aplikasi selesai dibuat, lalu di ke dalam bentuk .apk, ketika proses build selesai kemudian install, dan jalankan aplikasi.

\section{HASIL DAN PEMBAHASAN}

Pada tahap implementasi, dilakukan uji coba sistem pada aplikasi yang sudah dibuat. Hal yang di uji coba adalah aplikasi yang di buat menggunakan Unity 3D dapat mendeteksi objek marker dengan semestinya. Kemudian berhasil menampilkan display berupa objek 3D dan popupdeskripsi tentang objek tersebut, yaitu tugu pahlawan dan patung Soekarno-Hatta, platform yang digunakan untuk pengujian adalah Platform Android versi Android 10 atau Android Q, dan metode yang digunakan untuk pengujian aplikasi adalah black box testing untuk mengetahui apakah aplikasi berfungsi sesuai rancangan

\section{A. Flowchart Aplikasi}

Flowchart adalah adalah suatu bagan dengan simbol-simbol tertentu yang menggambarkan urutan proses secara mendetail dan hubungan antara suatu proses (instruksi) dengan proses lainnya dalam suatu program. Berikut adalah flowchart dari aplikasi.

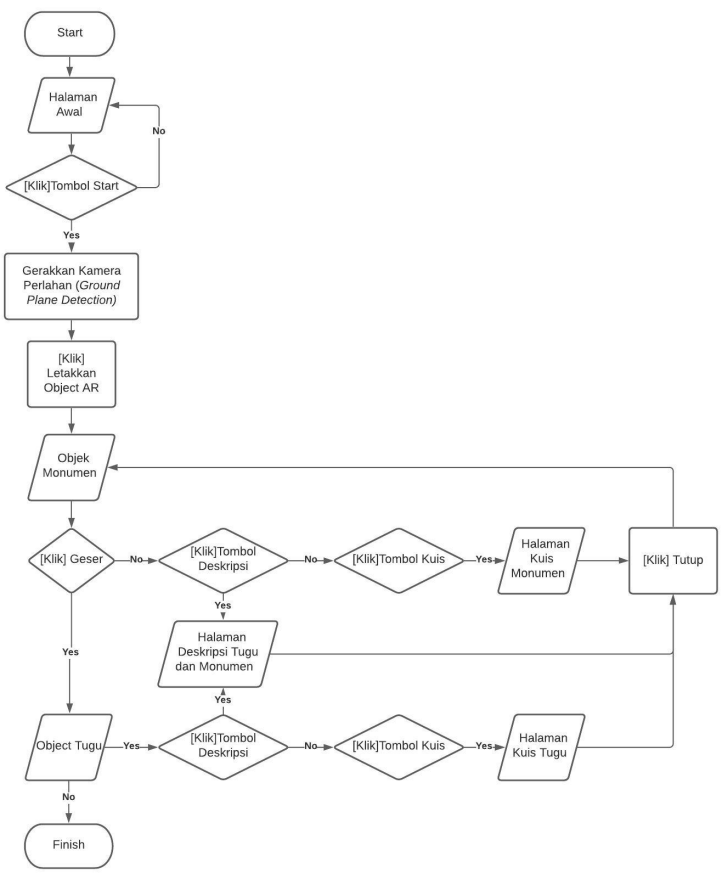

Gambar 3. Flowchart Aplikasi

\section{B. Implementasi}

Implementasi adalah proses yang dilakukan untuk menerapkan hasil dari rancangan yang sudah dibuat. Berikut adalah implementasi dari aplikasi. 


\section{Jurnal Sistem Komputer dan Kecerdasan Buatan}

Vol. IV No. 2 Tahun 2021

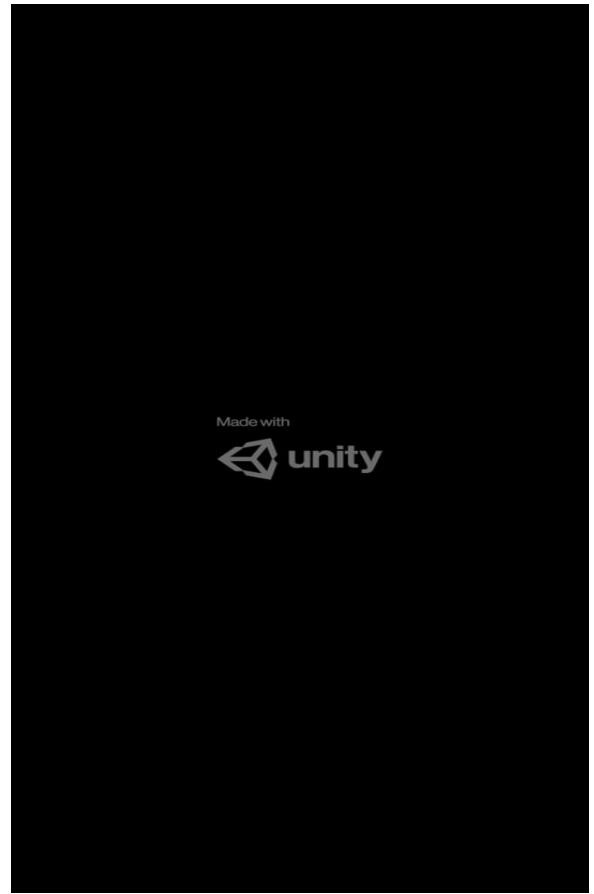

Gambar 4. Halaman Splashscreen

Halaman Splashscreen merupakan tampilan tambahan yang muncul saat pertama kali kita membuka suatu aplikasi. Splashscreenini biasanya digunakan untuk "Branding" dari pemilik aplikasi tersebut.

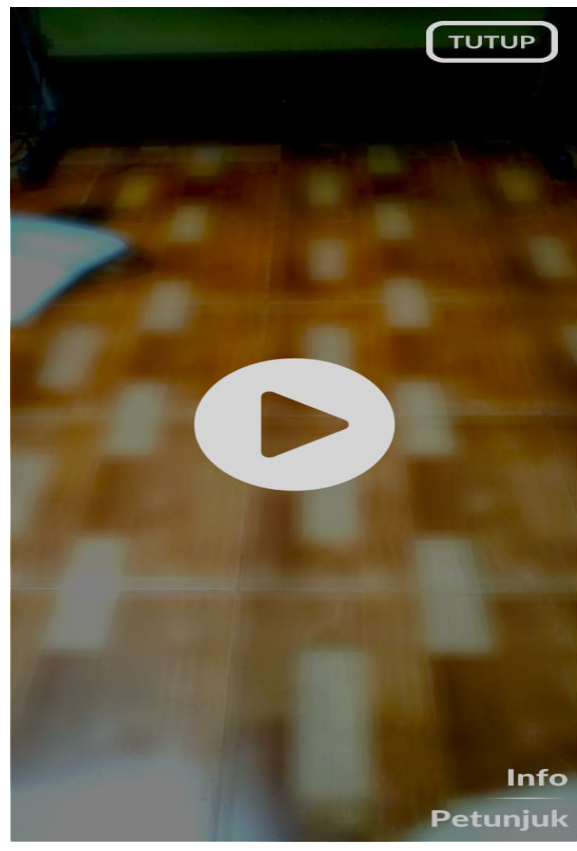

Gambar 5. Halaman Awal

Halaman awal merupakan halaman yang akan tampil setelah splashscreen, pada halaman awal ini terdapat 4 tombol dengan fungsi yang berbeda-beda. Tombol yang bergambarkan logo Play adalah tombol yang berfungsi untuk melanjutkan ke halaman selanjutnya, yaitu halaman ground plane scanning yang digunakan untuk mendeteksi groundyang akan digunakan untuk meletakkan objek 3D yang sudah disediakan, tombol Info digunakan untuk menunjukkan info aplikasi, tombol Petunjuk digunakan untuk petunjuk dasar, dan tombol Tutup untuk menutup aplikasi.

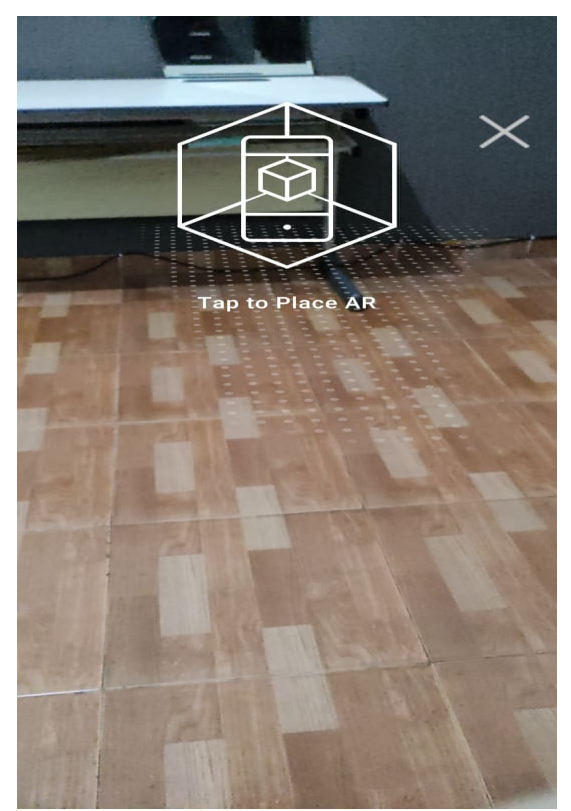

Gambar 6. Halaman Ground Plane Scanning

Halaman Ground Plane Scanning merupakan halaman yang berfungsi untuk mendeteksi ground yang akan digunakan untuk meletakkan objek 3D yang sudah terdaftar, yaitu Tugu Pahlawan Surabaya dan Monumen SoekarnoHatta dan disertai tombol Exit untuk membatalkan Scan dan kembali ke halaman awal. 


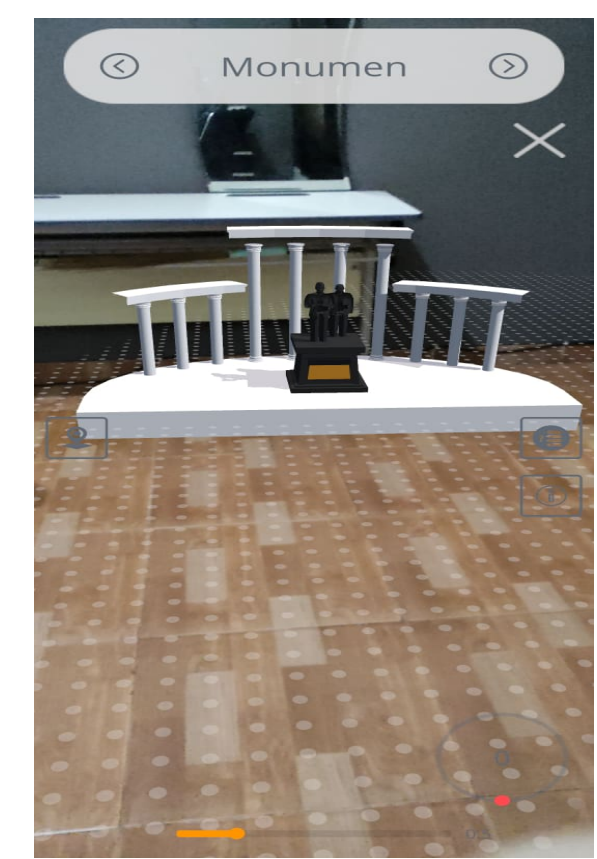

Gambar 7. Halaman Objek Monumen

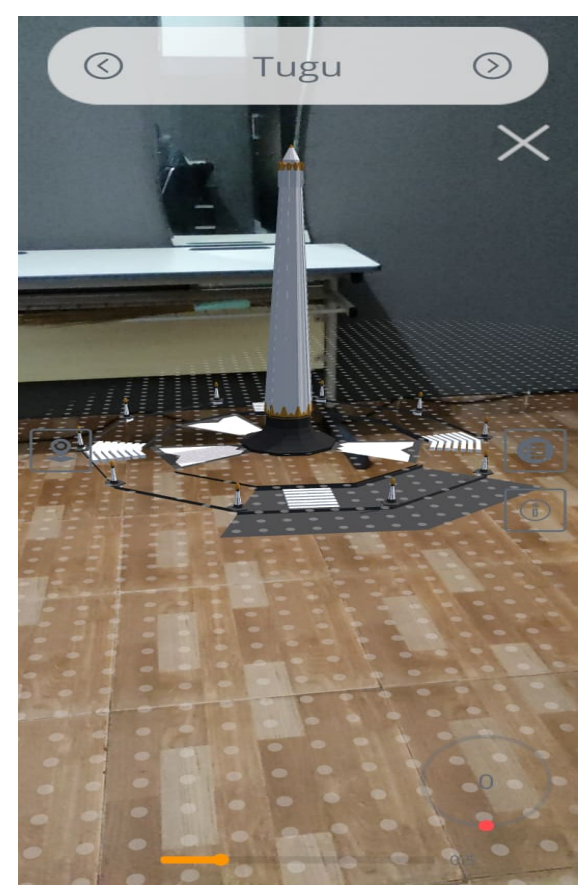

Gambar 8. Halaman Objek Tugu

Halaman Utaman Objek Monumen dan Tugu merupakan halaman yang akan ditampilkan setelah proses Ground Plane Scanning selesai dan sukses meletakkan objek AR. Terdapat 8 tombol yang memiliki fungsi masing-masing, yaitu tombol Exit untuk kembali ke halaman awal sebelum menutup aplikasi, tombol geser kanan dan kiri untuk mengganti objek 3D yang ingin ditampilkan, tombol Move untuk memindah posisi objek 3D dalam area ground yang terdeteksi, tombol Quiz untuk menampilkan kuis tentang monumendan tugu, tombol Informasi untuk menampilkan deskripsi tentang 2 objek 3D yang tersedia pada aplikasi yaitu monumen dan tugu, tombol Resize warna oranye untuk mengubah ukuran objek 3D yang ditampilkan, dan tombol Rotate untuk memutar objek sampai dengan 360 derajat. Tampilan halaman utama objek monumen pada aplikasi ditunjukkan pada gambar 7 dan gambar 8 .

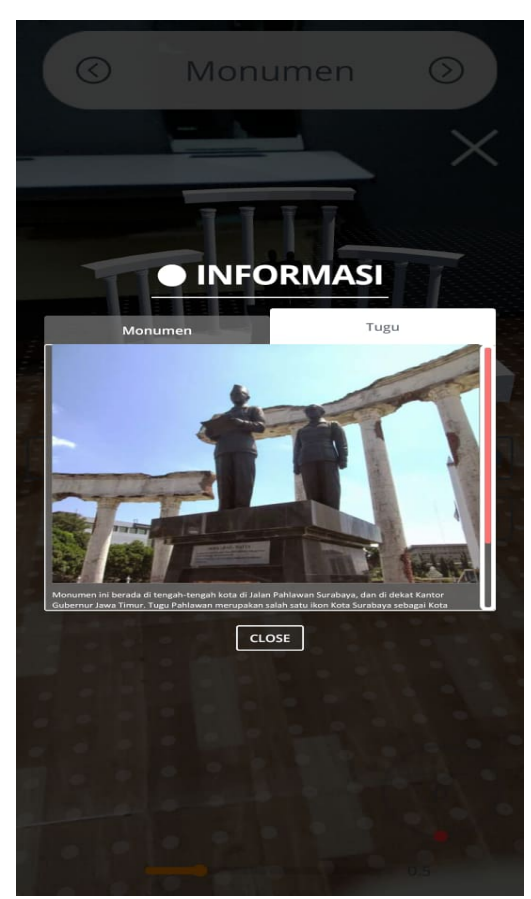

Gambar 9. Halaman Informasi Monumen

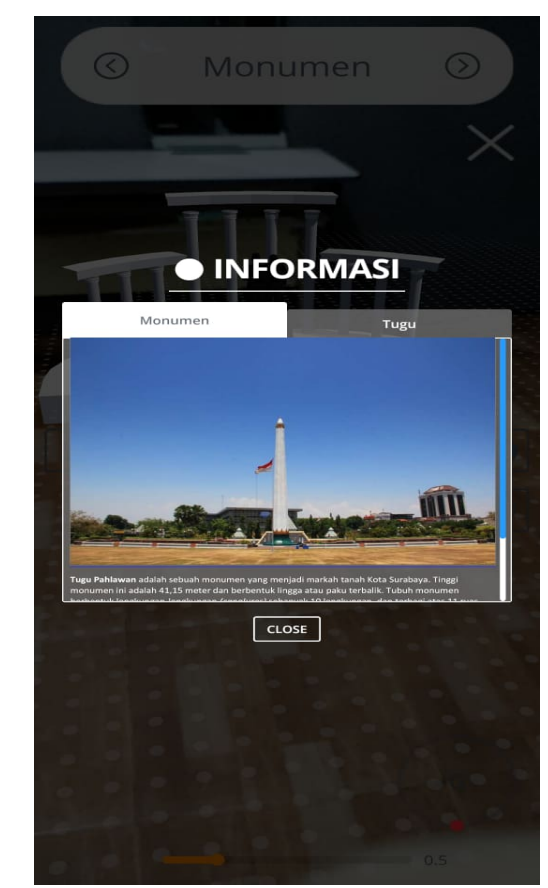

Gambar 10. Halaman Informasi Tugu 


\section{Jurnal Sistem Komputer dan Kecerdasan Buatan}

Vol. IV No. 2 Tahun 2021

Halaman Informasi merupakan halaman yang berisikan informasi tentang objek yang ditampilkan, yaitu Tugu Pahlawan Surabaya dan Monumen Soekarno-Hatta dan disertai tombol Close untuk menutup halaman Informasi. Tampilan halaman Informasi pada aplikasi ditunjukkan pada gambar 9 dan 10 .

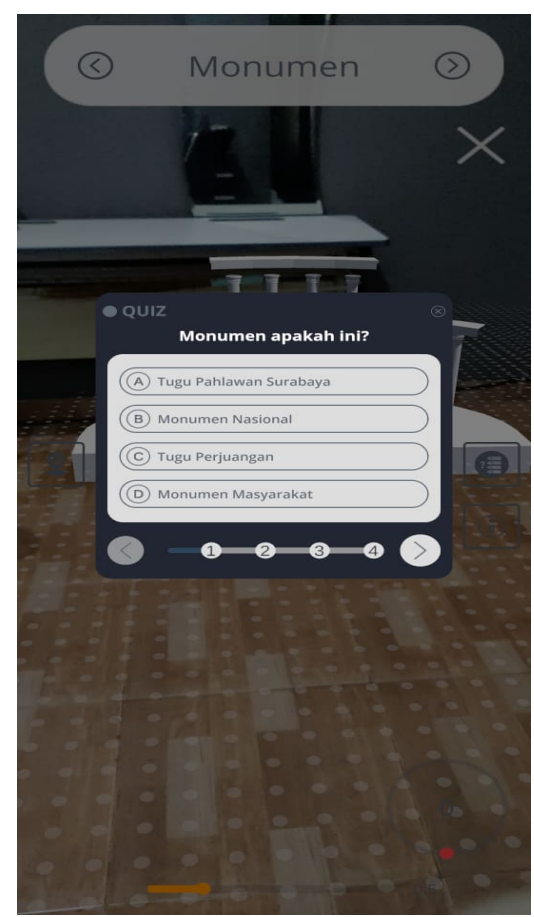

Gambar 11. Halaman Quiz Monumen

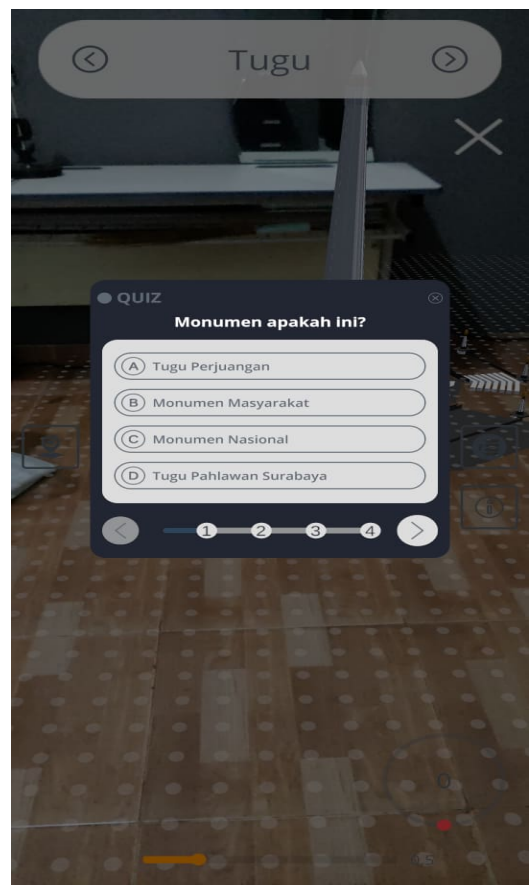

Gambar 12. Halaman Quiz Tugu
Halaman Quiz merupakan halaman yang berisikan kuis tentang objek yang ditampilkan, yaitu Tugu Pahlawan Surabaya dan Monumen Soekarno-Hatta, kuis yang ditampilkan memiliki masing-masing 4 pertanyaan tiap objek, dan 4 pilihan ganda tiap pertanyaan, pertanyaan yang dilampirkan seputar objek yang sudah dijelaskan di halaman Informasi, dan disertai tombol Exit untuk menutup kuis. Tampilan halaman Quiz pada aplikasi ditunjukkan pada gambar 11 dan 12.

\section{Hasil Pengujian}

Pengujian aplikasi menggunakan gadget dengan spesifikasi Chipset Snapdragon $732 \mathrm{G}$, Android 10, MIUI 12, dan RAM 6GB + ROM 64GB kepada pengguna bertujuan untuk mengetahui apakah aplikasi dapat memberi manfaat kepada pengguna. Aplikasi $A R$ Edukasi Tugu Pahlawan ini diperkenalkan kepada 20 masyarakat untuk mengenali dua objek yaitu Tugu Pahlawan Surabaya dan Monumen Soekarno-Hatta. Pengujian yang digunakan menggunakan kuisioner yang berisi dengan 6 pertanyaan. Pengguna diharuskan menjawab kuisioner untuk mengetahui penilaian dari aplikasi. Kuisioner pada tabel berikut berisi tentang pertanyaan seputar aplikasi.

\begin{tabular}{|l|l|l|l|c|l|}
\hline \multirow{2}{*}{ No } & \multirow{2}{*}{ Pertanyaan } & \multicolumn{4}{|c|}{ Jawaban } \\
\cline { 3 - 7 } & & A & B & C & D \\
\hline 1 & Desain Aplikasi & 11 & 9 & 0 & 0 \\
\hline 2 & Informasi yang ditampilkan & 7 & 10 & 3 & 0 \\
\hline 3 & Visual dari Objek 3D & 4 & 11 & 5 & 0 \\
\hline 4 & Aplikasi Mudah Digunakan & 15 & 5 & 0 & 0 \\
\hline 5 & Kuis menarik & 8 & 8 & 4 & 0 \\
\hline 6 & Ketertarikan dengan aplikasi & 10 & 6 & 4 & 0 \\
\hline Total & & 55 & 49 & 16 & 0
\end{tabular}

Menurut Machfoedz (2007) secara keseluruhan penilaian dari kuisioner yang dilakukan dapat dihitung dengan menggunakan rumus berikut:

$\mathrm{Pk}=(\mathrm{f} / \mathrm{N}) * \mathrm{Ikb}$

Dimana:

$\mathrm{Pk}=$ Persentase untuk $\mathrm{k}$ kondisi dalam hal sangat baik, baik, cukup baik, dan buruk.

$\mathrm{f}=$ Total respon dalam $\mathrm{k}$ kondisi.

$\mathrm{N}$ = Jumlah total pertanyaan dikalikan total respon $(6 \times 20=120)$ 
$\mathrm{Ikb}=$ Interpretasi $\mathrm{k}$ kondisi terbesar yaitu kurang $25 \%$, cukup baik $50 \%$, baik $75 \%$, dan sangat baik $100 \%$

Persentase hasil kuisioner dapat di hitung dengan rumus diatas, untuk masing-masing kategori dapat diperoleh sebagai berikut :

1. $\mathrm{P}$ sangat baik $=(55 / 120) * 100 \%=45.83 \%$

2. $\mathrm{P}$ baik $=(49 / 120) * 75 \%=30.63 \%$

3. $\mathrm{P}$ cukup baik $=(16 / 120) * 50 \%=6.67 \%$

4. $\mathrm{P}$ buruk $=(0 / 120) * 25 \%=0.00 \%$

Total persentase $=$ Psangat baik + Pbaik + Pcukup baik + Pburuk, sehingga didapat nilai sebesar $83.13 \%$ yaitu kategori sangat baik.

\section{SIMPULAN}

Berdasarkan hasil penelitian Game Edukasi Tugu Pahlawan Surabaya Dengan Augmented Reality Berbasis Android didapatkan kesimpulan sebagai berikut: Game Edukasi Tugu Pahlawan Surabaya Dengan Augmented Reality Berbasis Android dapat memperkenalkan Tugu Pahlawan Surabaya dan Monumen Soekarno-Hatta dengan cara yang lebih mudah karena bisa diakses dari mana saja. Hasil dari Game Edukasi Tugu Pahlawan Surabaya Dengan Augmented Reality Berbasis Android dapat membantu pengguna aplikasi untuk mengenal dan mengetahui informasi tentang Tugu Pahlawan Surabaya dan Monumen Soekarno-Hatta dengan menggunakan permainan dan kuis didalam aplikasi sebagai sarana pembelajarannya.

\section{DAFTAR PUSTAKA}

[1] Pungky Ary Wibowo, Endah Sudarmilah. 2015. “Aplikasi Augmented Reality Game Edukasi Untuk Pengenalan Organ Tubuh Manusia"

[2] Azuma, Ronald T. 1997. "A Survey of Augmented Reality". Presence: Teleoperators and Virtual Environments 6 (4): 355-385

[3] "Cara Kerja Augmented Reality". https://garudacyber.co.id/artikel/1393-carakerja-markerless-augmented-reality

[4] "Apa itu unity 3D?". https://akbarproject.com/apa-itu-unity-3d/

[5] “Apa itu Blender 3D?" https://laskarblender.wordpress.com/apaitu-blender-3d/ 